\title{
Hydrodynamic modeling for the sustainable management of the guájaro hydrosystem, Colombia
}

Torres Bejarano, Franklin Manuel; Padilla Coba, Jesus; Ramírez León, Hermilo; Rodríguez Cuevas, Clemente; Cantero Rodelo, Ruben Dario,

\begin{abstract}
The Guájaro reservoir is the most important water body located at the north of Colombia. It is supplied by an artificial channel (Canal del Dique) through a two floodgates system. As a result of excess nutrients and other pollution loads from the drainage basin in recent decades, the Guájaro reservoir suffers eutrophication and other pollution problems; however it still continues being exploited. For this reason, it is necessary to regulate the hydraulic structures that supply this water body, as they play an important role in managing levels, and these in turn for water supply and environmental purposes. The present work is carried out as a sustainability management alternative of the reservoir. The implementation of a two-dimensional hydrodynamic model and its calibration is achieved using time series of the free surface levels, and comparing the measured velocities and those estimated by the model for two different climatic periods, to assist the operation of the Canal del Dique-Guájaro hydrosystem. The corresponding comparisons showed a good behavior between measured and simulated data. Based on the quantitative results of the Nash-Sutcliffe reliability method, the results are considered quite satisfactory for estimating and predicting the amount of water flowing in and out of the reservoir through the channel reservoir hydrosystem.
\end{abstract}

\section{keywords}

Captaciones, Eutrofización, Dinámica de fluidos, Estructuras hidráulicas, Hidrodinámica, Contaminación, Manejo de reservorios, Desarrollo sostenible, Suministro de agua 